\title{
Restructuring a Production Company Into A Production logistics Centre
}

\author{
KREMLJAK, Z. \& HOCEVAR, M.
}

Abstract: In the chapter the contemporary method of warehousing operations by optimizing business processes in textile industry is described, and a new customerproducer relation is introduced, with appropriate technological equipment, IT support, reducing storage space, the new operating system functions with optimized supply chain. The new business system provides greater flexibility between the client and the producer, and other customers and thereby maintains the market share, which is very important for all business systems in the EU textile industry, according to the globalization on the difficult market in this area.

The presented system functions without major social disturbances, i.e. it is stable and has optimized production process. This idea will be expanded in future.

Key words: Restructuring, Manufacturing, Logistics Centre, Supply Chain, SWOT Analysis
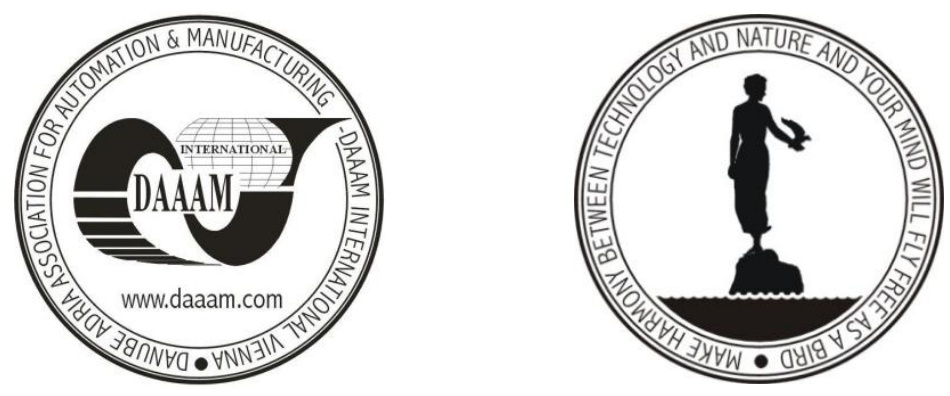

Authors' data: Asst. Prof. Dr. Sc. Kremljak, Z[vonko]*; Full Prof. Dr. Sc. Hocevar, M[arko]**, *Telekom Slovenije, d. d. (ONE Telecommunications Services MK), Cigaletova 15, SI - 1000 Ljubljana, Slovenia, European Union, **University of Ljubljana, Faculty of Economics, Kardeljeva ploscad 17, SI - 1000 Ljubljana, Slovenia, European Union, zvonko.kremljak@s5.net, marko.hocevar@ef.uni-lj.si

This Publication has to be referred as: Kremljak, Z[vonko] \& Hocevar, M[arko] (2014). Restructuring a Production Company Into a Production Logistics Centre, Chapter 06 in DAAAM International Scientific Book 2014, pp.071-086, B. Katalinic (Ed.), Published by DAAAM International, ISBN 978-3-901509-98-8, ISSN 17269687, Vienna, Austria

DOI: 10.2507/daaam.scibook.2014.06 
Kremljak, Z. \& Hocevar, M.: Restructuring a Production Company Into a Productio...

\section{Introduction}

The logistics business philosophy aims to promote interdisciplinary cooperative action. It requires a broader aspect of the observation that goes beyond the narrow scope of the individual's performance, the courage to individual responsibility and ability to communicate in order to overcome complexity in a better way. It may be noted that the logistical mind-set is focused on two key principles:

- integrity and

- customer orientation (service).

The customers' expectations in terms of the level of logistics services become higher. The competition in the mature textile industry market is large and the buyers expect high quality and cost-efficient logistics services. The buyers require shorter delivery time, delivery of smaller quantities of wide variety of products in a "time window", i.e. at specific times at the point of sale, where mechanical reloading has been installed, including additional services. The additional services may include unloading at the recipient, delivery to the end recipient etc.

In defining the components of the entire logistics system, all its components shall be included without which it won't be able to perform its task and achieve the set goals, i.e. it wouldn't be able to exist (Rudberg \& Olhager, 2003):

- external transport,

- internal transport,

- storage,

- stocks,

- handling goods, information, communication and control, and

- personnel related to the system.

With the enlargement of the European Union the movement of goods became easier and faster. The storage capacities and the secondary transport became the bottleneck in the emerging markets in the EU. These circumstances require examination of the possibilities and concepts of the logistics services within the company.

In order to maintain or improve market competitiveness, it is necessary to find the right balance between the level of the logistics services and the costs thereof.

Based on its long-term vision, the company will transform from production company into a production logistics centre (Kremljak, 2010).

There are several different ways for achieving the set goals. During the selection of means for optimization of the output logistics, the optimal costs, the compatibility with the existing organization and the feasibility shall be taken into consideration. The following logistics systems shall be part of the transformation process:

Global logistics is a combination of national and international logistics activities that provide for successful implementation of the logistics services within the global logistics systems. The process of globalization has particularly reduced the barriers and limits on the movement of people, goods, services, knowledge, capital and information. It may be defined as a composite, dynamic and stochastic system of logistics events which represent a group of coordinated, integrated and controlled 
global logistics activities that provide for the achievement of the strategic goals in the separate frames of the global logistics system (Al-Hawari et al., 2013).

Macro-micro-meta logistics: the macro-logistics system includes two or more micro-logistics systems which in practice are focused on the national economy within the country. This includes adjustment of the goods flow to the structure and the characteristics of the end recipients of goods and services within the economy. In terms of content, it deals with analysing the impact of the economic, traffic and transport policy of each country in relation to the performance of the logistics companies. At macro level we talk about logistics phenomena of the functional logistics branches such as manufacturing, trade, transportation, forwarding and other types of logistics. The micro level defines the logistics of manufacturing, purchase, marketing, distribution etc. The meta-logistics represents the internal organizational systems that go beyond the legal and organizational limits, such as organization or institution. It emphasizes the partnership between the companies and the division of responsibilities which are developing long-term relationships with the buyers, suppliers, intermediaries, transport and storage companies, as well as with logistics companies which may have an impact on increasing the performance of a certain company or companies.

Inter- and Intra-logistics: analyses the relationships between the logistics operators in developing the logistics activities within the logistics system. The development is subject to the processes of internationalization of the operations due to the increased market competitiveness, the development of transport infrastructure and superstructure, telecommunications, strategic connections and the general globalization of doing business.

Let us focus on the optimization of transport, the structure of warehouses and the logistics service providers. The common feature of all three flows is the optimization of logistics through the entire chain of company-(storage)-buyer.

\section{Supply chain of the company - concepts and definitions}

The logistics organization is mainly promoted by the following factors:

- Globalization of markets as spatial expansion of supply and sales markets not only at local, continental level but also worldwide increased, for example, the complexity of transportation routes and the combination of transport and ultimately resulted in increase of competitiveness. This has increased the number of participants on the way from the purchase of the necessary raw materials to manufacturing and on to intermediaries and end consumers. Such large logistics corporations are continually spreading their global logistics network through new strategic relations, merger and associations, as well as through taking over smaller companies. Consequently they ensure availability of their logistics services in the entire world.

- Development of information technology (e-operations and e-commerce) which on the one hand promotes doing business in the segment of supply of goods, and on the other hand for most of the cases it creates the need of increased physical distribution (physical delivery) as soon as possible.

- Outsourcing - due to the increased market competition, the companies have to be limited to their main business activity, while the auxiliary activities (such as 
logistics, storage, distribution, packaging etc.) must be assigned to third companies (Anderson \& Morrice, 2000).

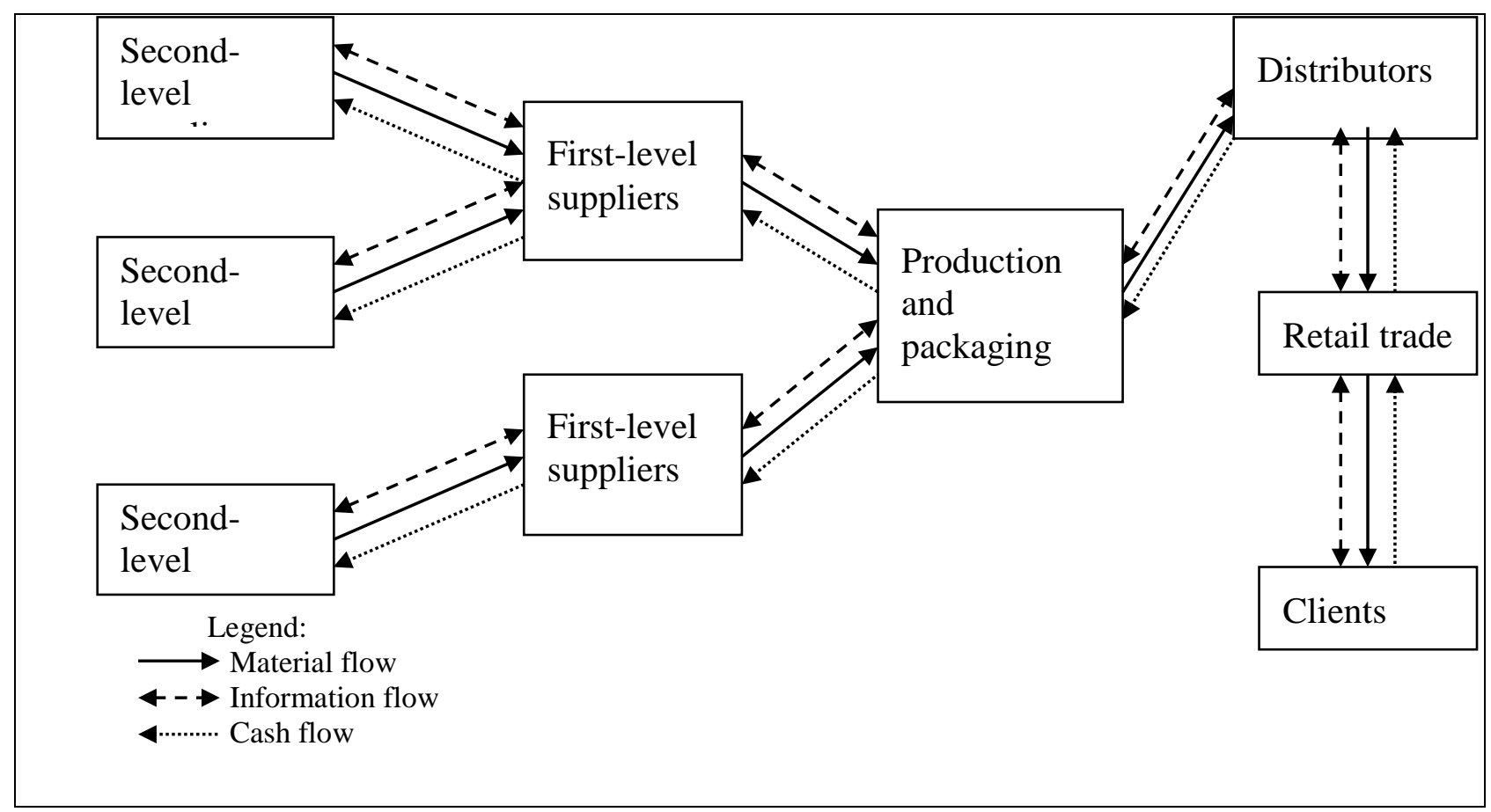

Fig. 1. Example of a simple linear supply chain

The information flow is common, since all participants in the supply chain depend on it (Fig. 1):

- Information confirming that all operations between the suppliers, manufacturers, distributors and retailers are coordinated and that the material flow is uninterrupted.

- The second-level suppliers must receive information about the ongoing delivery of the necessary materials, raw materials etc. and at the same time they provide information about their capacity to ensure continuous material flow. The firstlevel suppliers coordinate the information flow with the purchase and exchange information with the second-level suppliers, as well as with the manufacturers.

- Through exchange of information the manufacturing ensures a sufficient amount of components, semi-finished goods etc. depending on the needs of the manufacturers and distributors.

- Through the information flow, the distribution coordinates the supply and demand of the customers and distributors and ensures that the product arrived at the customer in the optimal quantity (Pujawan, 2008).

The cash flow travels in the opposite direction as the material flow. The cash flow is the key to ensuring the continuity of the entire supply chain. Supply chain performance and production performance have a large impact on costs and sales.

The introduction of improvements brings along a number of additional categories and criteria, such as optimization and regular monitoring of the costs, the flow and productivity. In modern time these criteria apply mostly to storage, transport and stocks. The companies are increasingly focusing on the customers as follows:

- they decrease the response time to customers' requirements, 
- they improve the quality of products and services.

At the same time they put greater emphasis on long-term teamwork and management. In addition to the need for operational criteria in logistics, these changes impose the need of introducing new type of more strategic criteria which reflect how well the processes of the value chain within the company are adding value to the customer, which represents a significant competitive advantage for the company.

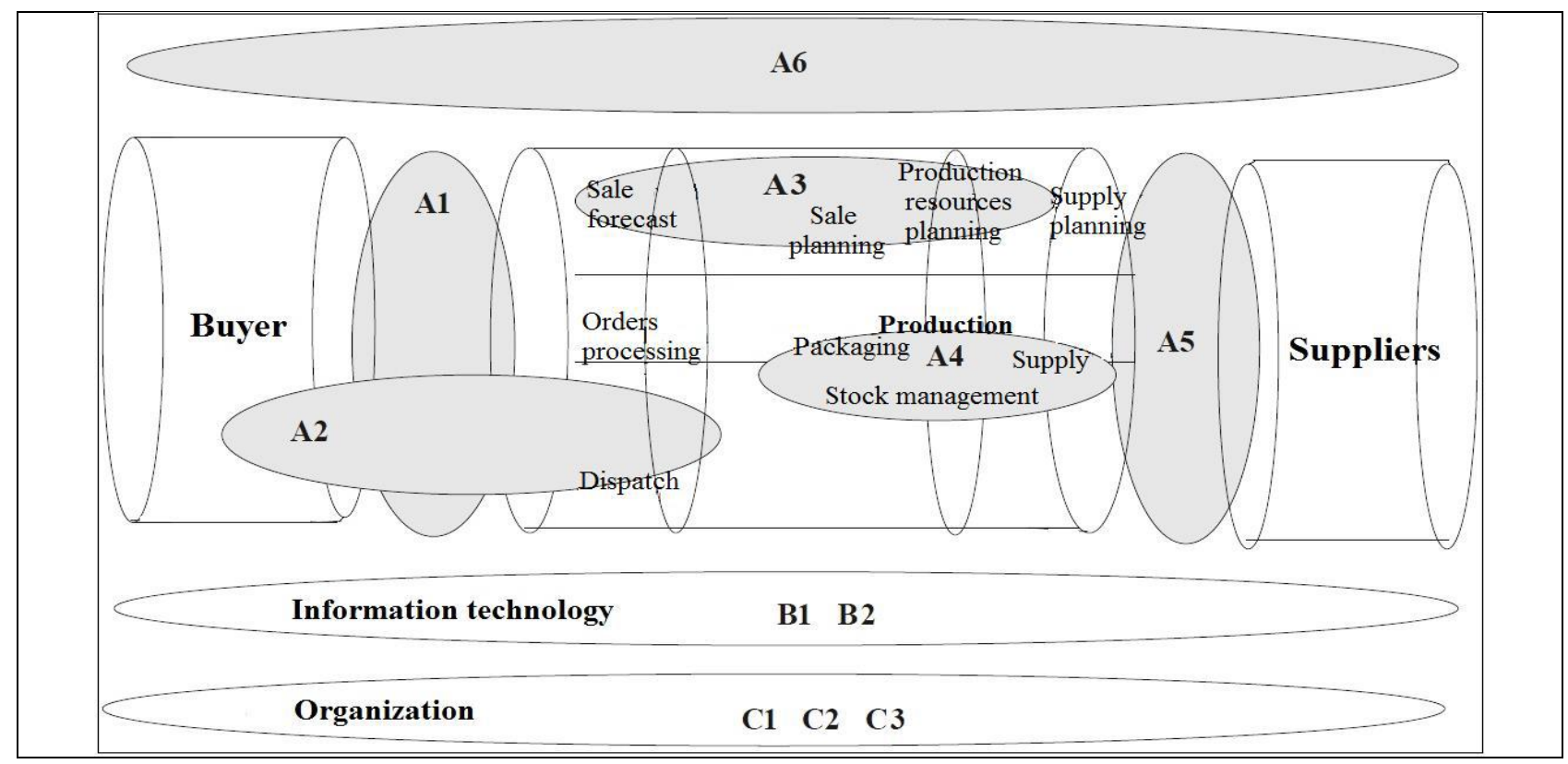

Fig. 2. Value chain structure

Fig. 2 (above) shows how complex the structure of the supply value chain is: A. Value chain processing options

A1. The dialogue with the customer about the value chain allows manufacturers to understand the needs of their customers and at the same time it provides solutions that add value.

A2. The efficient distribution has the ability to transfer goods and materials from suppliers to production and then on to the customers. The interconnections enable optimal use of the resources for the provision of the mentioned distribution.

A3. Planning Sales on Demand means:

- accuracy of the sales and marketing forecasts for the product and its continuous use in production plans,

- planning and managing sales and distribution and after-sales activities.

A4. Support of production

Provision of so-called efficient production by efficient use of the production capacity, which achieves high level of efficient use of the equipment with minimal changes, small stocks and short times of reorganization (change over times), as well as a high level of flexibility and quality.

A5. Partnership with suppliers means integration of all activities of the manufacturer and the supplier, which in return increases the value and cost-effectiveness of purchased materials and services. 
Kremljak, Z. \& Hocevar, M.: Restructuring a Production Company Into a Productio...

A6. Integrated value chain management means operation, i.e. supply chain management at two levels, namely:

- management of the operations of the company and its affiliated companies,

- strategic analysis of costs and implementation options.

B. Information technology capability

B1. Integrated Information Systems means improved quality and timeliness of business information in a common database, which manages planning and supply chain activities. That leads to achievement of high integrity and consistency of the decision-making process.

B2. Advanced information technology

Advanced technology improves the efficiency of business operations and provides new ways of managing the supply chain.

C. Organizational skills

C1. Comprehensive assessment of the activities implementation

Allows transfer of business objectives into specific operational and financial plans for individual elements of the supply chain. The regular inspections and analysis of the supply chain activities is of use for both the suppliers and the customers.

$\mathrm{C} 2$. Teamwork is based on the training individuals, which facilitates the ability of employees to cooperate effectively, to achieve broader business objectives and to improve their performance.

C3. Related organizational structure represents mutual organizational links between all participants in the supply chain, which aims to support business processes.

As we have already stated, the entire chain consists of suppliers, manufacturers, distribution channels, interconnection networks and relationships in the production or with the model "plug to plate". with the model "plug to plate".the supply of services. with the model "plug to plate". with the model "plug to plate". with the model "plug to plate".A good illustration of the value chain (Fig. 3) can be made

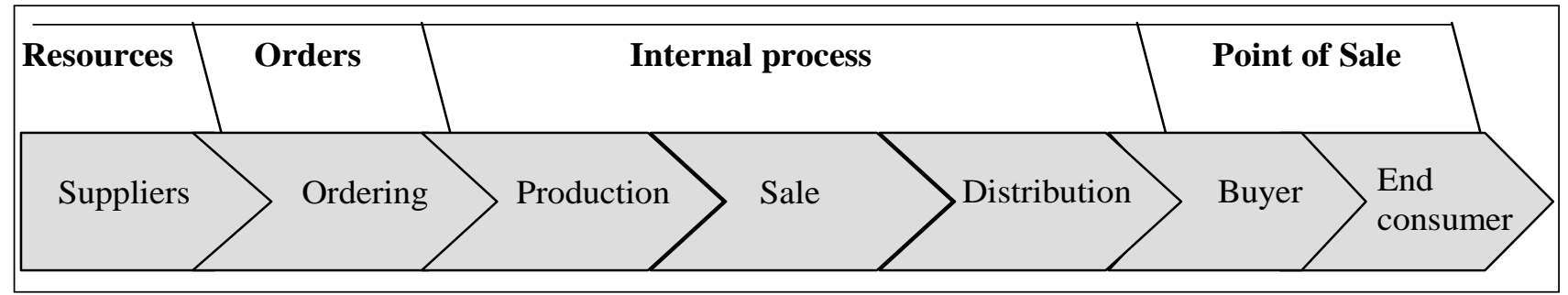

Fig. 3. Logical course of the value chain

The value chain covers the flow of goods from the suppliers, through manufacturing and distribution channel to the end user. The company is a box which is divided into the information flow from right to left and the goods flow from left to right. The function of planning is the basis for the perception of demand in any form, either in the form of a sale contract, forecast, planned level of stocks etc. and it transforms the demand into a form. 


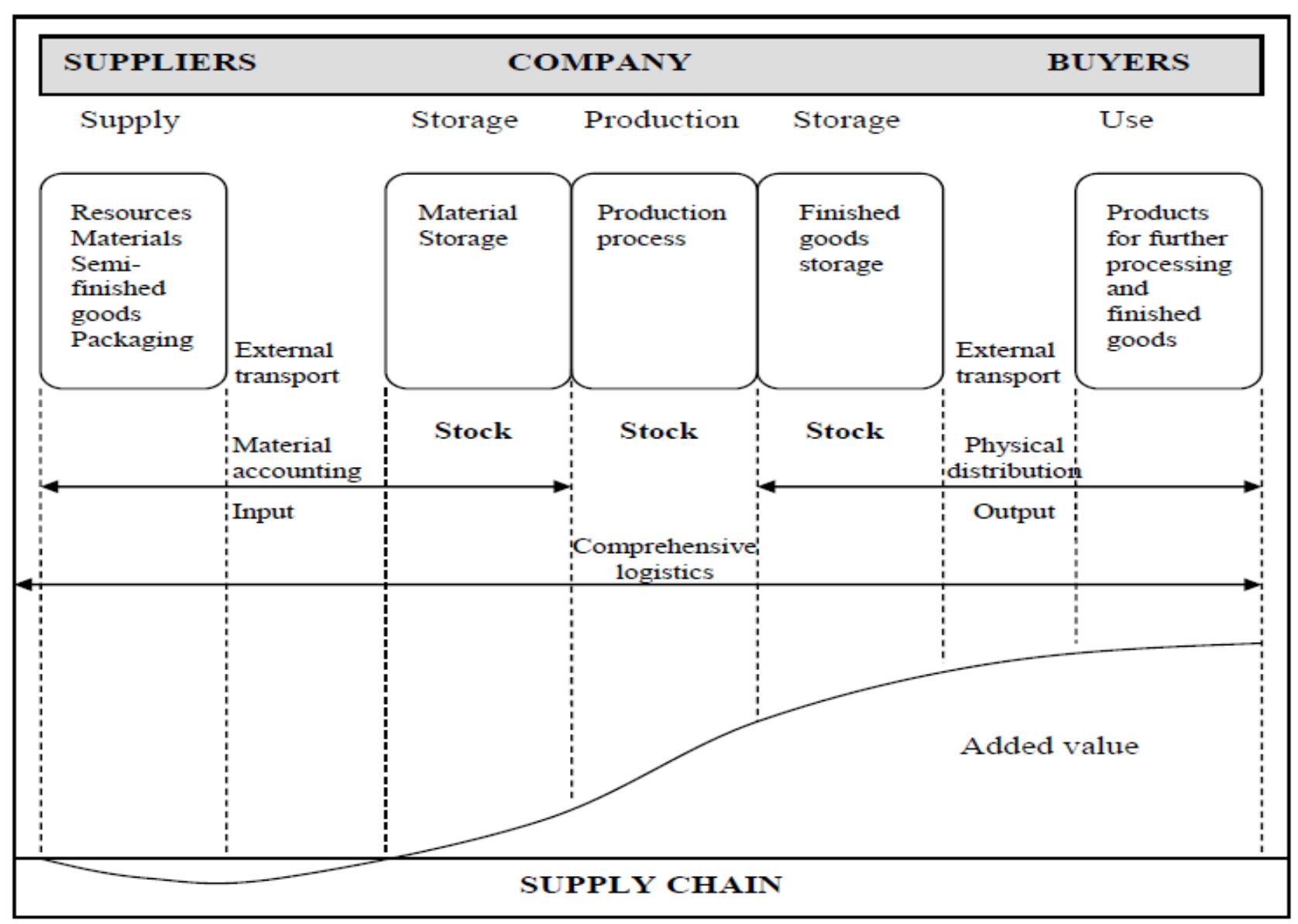

Fig. 4. Scope of the supply chain and added value movement

Therefore, the entire chain supports three types of flows:

- Material flow, which represents the physical flow of goods from suppliers to customers, as well as the reverse flow of returning products, servicing and recycling;

- Information flow ${ }_{2}$ which represents the transmission of orders and traceability of orders and coordinates the physical flow of the goods;

- Cash flow, which includes credit terms, payment schemes, supply contracts and ownership.

Material flow exists in one direction (from the supplier to the customer), cash flow is in the opposite way, but information flow exists in both directions.

The support includes (Fig. 4 and Tab. 1):

- processes that cover the capacity of the company in logistics, new product development and knowledge management;

- organizational structure, which includes system of relations beginning from total vertical integration to network companies, as well as approaches of the management, performance criteria and reward schemes;

- technology $y_{2}$ which combines both processes and information technology. An efficient supply chain requires the integration of all processes from procurement to distribution of products to the customers.

The main decisions in the chain cover four main areas: 
- Location, which includes decisions regarding the location of the production facilities, storage and supply points. After the location is defined, the path of a product from the plant to the consumers is to be determined. At the same time, defining the location represents a market entry strategy, since the revenues, costs and consumer supply level depends on it. When making a decision, the company shall consider all these effects, as it is a long-term strategic decision.

\begin{tabular}{|c|c|c|}
\hline ELEMENT & $\begin{array}{l}\text { TRADITIONAL } \\
\text { APPROACH } \\
\end{array}$ & SUPPLY CHAINS \\
\hline Management of stocks & Independent efforts & $\begin{array}{l}\text { Joint decrease of channel } \\
\text { stocks }\end{array}$ \\
\hline Total costs & $\begin{array}{l}\text { Minimization of company's } \\
\text { costs }\end{array}$ & $\begin{array}{l}\text { Efficiency over the entire } \\
\text { channel }\end{array}$ \\
\hline Time horizon & Short-term & Long-term \\
\hline $\begin{array}{l}\text { Amount of shared and } \\
\text { controlled information }\end{array}$ & $\begin{array}{l}\text { Limited to the need of } \\
\text { current transactions }\end{array}$ & $\begin{array}{l}\text { As required for planning and } \\
\text { controlling processes }\end{array}$ \\
\hline $\begin{array}{c}\text { Coordination of } \\
\text { multiple levels in the channel }\end{array}$ & $\begin{array}{l}\text { Single contact for } \\
\text { transactions between the parties in } \\
\text { the channel }\end{array}$ & $\begin{array}{l}\text { Multiple contacts between the } \\
\text { company's levels and channel's } \\
\text { levels }\end{array}$ \\
\hline Joint planning & Transaction based & Permanent \\
\hline $\begin{array}{l}\text { Compatibility of } \\
\text { corporate philosophy }\end{array}$ & Not necessary & $\begin{array}{l}\text { Compatible at least for the } \\
\text { main relations }\end{array}$ \\
\hline $\begin{array}{l}\text { Supplier database } \\
\text { volume }\end{array}$ & $\begin{array}{c}\text { Large for enhancing } \\
\text { competition and risk dispersion }\end{array}$ & $\begin{array}{l}\text { Small for increasing } \\
\text { coordination }\end{array}$ \\
\hline Channel management & Not necessary & $\begin{array}{l}\text { Necessary for focusing } \\
\text { coordination }\end{array}$ \\
\hline $\begin{array}{l}\text { Amount of diffuse risk } \\
\text { and rewards }\end{array}$ & Each in one place & $\begin{array}{l}\text { The risks and rewards are } \\
\text { divided on long-term basis }\end{array}$ \\
\hline $\begin{array}{l}\text { Operations, } \\
\text { information and stock flow } \\
\text { speed }\end{array}$ & $\begin{array}{l}\text { Orientation to warehouse } \\
\text { (storage, safety stock) disturbed by } \\
\text { flow obstacles; localized on } \\
\text { channel pairs }\end{array}$ & $\begin{array}{l}\text { Orientation to distribution } \\
\text { centre (stock speed), interrelated } \\
\text { flows, quick response along the } \\
\text { channel }\end{array}$ \\
\hline
\end{tabular}

Tab. 1. Comparison of traditional management and (supply) value chain management

- Production, which includes decisions about what to produce and in which facilities and about the allocation of suppliers in individual facilities. These decisions affect the revenues, costs and the level of consumer satisfaction with the company's performance. It is important to determine the production capacity, the assignment of products to the machinery and determination of the main production program.

- Stocks, which refers to the method of stocks management. Stocks are created at each stage of the supply chain as auxiliary goods, semi-finished or finished products. There are also inter-process stocks between individual facilities in different locations. Effective inventory management can significantly affect their reduction and by that the reduction in the costs associated with holding stocks.

- Transport, which is of strategic importance. These decisions are closely related to those for stocks, because the best decision on the method of transportation is often made by a decision on the costs of a particular mode of transport, which is indirectly related to the costs of the stocks. Therefore, the level of customer 
service and geographic location plays a key role in these decisions. The distance from the suppliers and the choice of transportation routes is also important.

\subsection{Key elements of the supply chain}

The extensive available literature indicates several variants of defining the key elements of the supply chain. We highlight three key elements, such as:

- Order fulfilment process: these are the activities that take place through the individual components of the supply chain and they include entering orders, confirming that everything goes according to the plan, confirming production, packaging, delivery and payment.

- Product life cycle management: this includes monitoring the entire supply chain, including the production of a prototype, product upgrades, repair and life cycle management.

- Supporting services: supply chain activities related to after-sales services, which aim to achieve customer satisfaction. These services include the availability of services, spare parts, regular versions of products in order to maximize customer satisfaction (Maleki et al., 2012).

An answer to these two questions gives the detailed analysis of the individual participants in the supply chain, their costs and the added value, as presented in Fig. 5 .

- Suppliers (and suppliers of suppliers): they are the first link in the chain. Most companies have a limited number of large suppliers, which provide about $80 \%$ of all incoming materials. The negotiations and partnership allow reducing the purchase price, higher quality and supply reliability.

- Relationship with the supplier: it offers an opportunity for a number of logistical savings based on location, time and transfer of ownership (in which phase of the materials movement shall the company enter the logistics process). In this relationship the company can reduce the stock up to $60 \%$, especially in the purchasing partnership, which also provides for savings due to the reduction of the number of documents, quality improvement, reduction of purchase prices, abandonment of entry control and faster flow of information in the electronic integration of the two partners.

- Company - Distributors Relationship: this is the phase of the logistics process and it is described as a narrow distribution system. The distribution system is designed for transfer of the final product to the point of sale (if necessary through warehouses and distribution centres). The analysis of the distribution system reveals opportunities for reducing stocks and faster transportation.

- Store-Customer Relationship: this is the final stage of the logistics process and its driving force, because without the purchase by the consumer the supply chain would not exist (Gilbert \& Ballou, 1999).

The individual relations between the distribution and the production are associated with the length of the production process. The longer the production process, the more it is associated with potential delays and changes in production lines, which can result in excessive stocks of finished products and lack of other stocks. Therefore, the tendency is short term production where the product is created 
Kremljak, Z. \& Hocevar, M.: Restructuring a Production Company Into a Productio...

as a reflection of production on demand. It also requires effective stocks management and flexible production lines (Fig. 5). Problems arise especially with seasonal demands, which are extremely difficult for the production to keep up with and they require the creation of certain seasonal stocks to meet seasonal demands. Production and distribution meet also within the company itself, especially in the delivery of materials necessary for the production process. The lack of raw materials stocks causes stagnation in production and/or an increase in production costs. Stagnation can be avoided by appropriate planning of production. Especially the physical distribution, as part responsible for the physical movement and storage of products for the consumers, plays a key role in relation to the sales function. The crucial element is the ability to offer the product in the right place, in sufficient quantities at the right time, with the appropriate service offered by the distribution (Simchi-Levi et al., 2003).

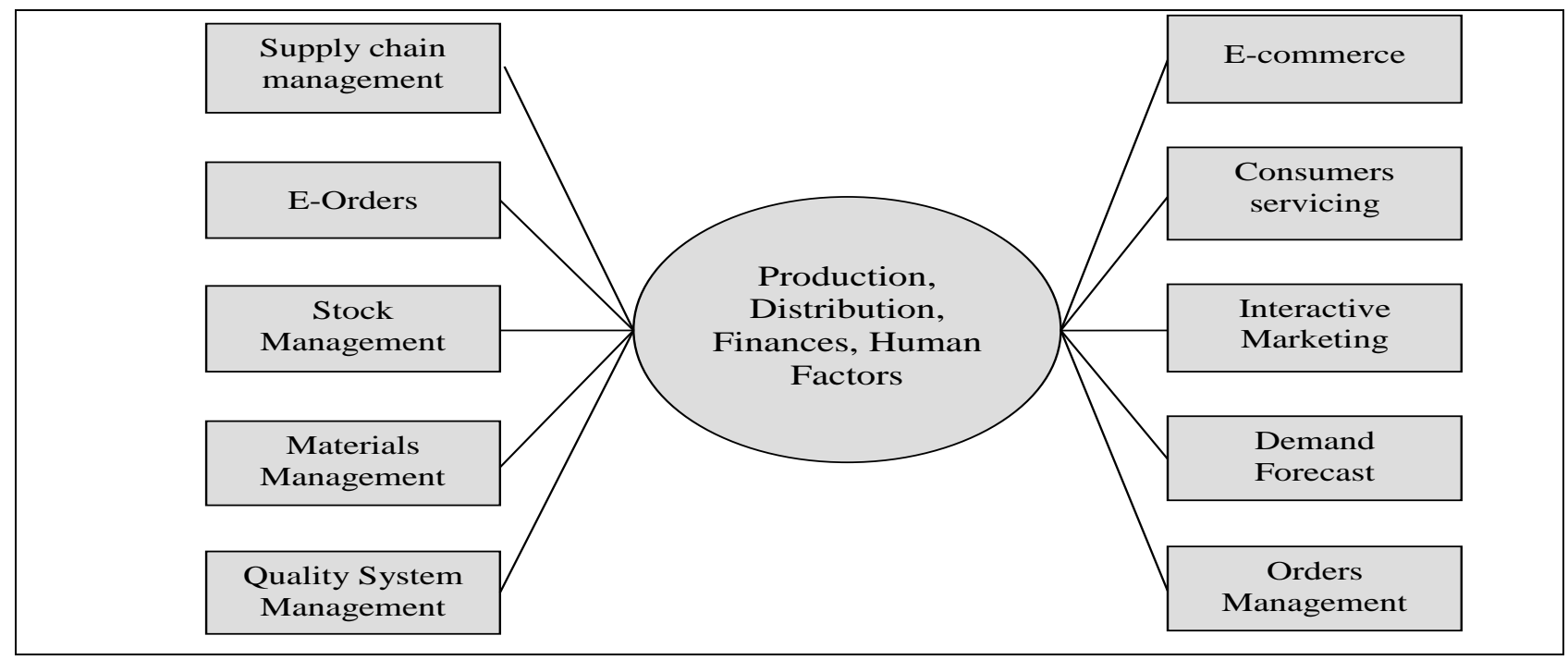

Fig. 5. Extended company

Consumers are one of the most important components of the supply chain. The company exists because of the consumers. Within the company there are only costs. Only the consumers achieve results because they buy the products produced by the company and they are willing to pay for them. Therefore, the consumer produces the value and the goal of the company is to adjust to the consumers and their expectations. Of course, one must not ignore the economic and non-economic factors. However, the tendency of consumers is to get the most for the money, over the other factors.

\section{Overview of the company's standing - progress of products logistics}

Before carrying out further analysis, the current situation should be overviewed. Until now the finished products are delivered to the customer who commissions them further to the ordering parties, packed in bags or cartons. For each client a label and a dispatch note is affixed to the bag or the carton. The prepared shipments are delivered to customer.

The company should take over the logistics for commissioning the products to the customer, packing the product in bags and cartons and transporting the goods to 
the warehouse of the buyer. The distribution of the products to the clients shall be realized by the buyer itself. In that way the existing technology of logistics is not substantially changed. The change refers to launching, packing products and printing self-adhesive labels (barcode), which will be adhered to the cardboard label of the buyer. From the cost point of view it is more favourable for the company.

A developed logistics system is an important development factor for the company. In particular, this depends on the requirements of particular markets (meeting the needs of consumers in a better way), the increase of international trade (and the integration of remote markets), the increasing complexity of production programs, the growing cost of material flow (power problem), the introduction of modern transport systems, etc. (Ouyang \& Li, 2010).

\subsection{Restructuring proposal-objectives and future perspectives}

The aim of the proposal is the selection of such logistical structure that will enable the lowest possible total cost, low primary transport costs, low secondary distribution costs by maintaining or improving the quality of the services (Zigart, 2008).

The warehouses that are not necessarily needed can be cancelled and the entire transport can be redirected to another warehouse. The question is whether the current warehouses are situated in locations that are optimal for doing business or is it necessary to rent out warehouses in other locations. The European market is quite unstable, at least for those countries that are subject to our analysis and therefore it is better to rent a warehouse instead of buying or building one.

\subsection{Development of logistics centre of the company}

The company's vision is leadership in Central and South-Eastern Europe for the complex fashion engineering, designed to the most demanding business partners and end-customers.

The company's mission is: technological innovations, quality of the materials, superior design in order to satisfy the desire for exclusivity and emphasized individuality in clothing in which people feel relaxed and sophisticated.

Strategic directions: gradual transformation from production into a fashion company which is able to organize production and logistics for the reputable European brands, using the knowledge for prominent market breakthrough of its own brands in the markets of Central, South and later in Western Europe.

One of the aims of the company is providing the entire logistics. Having the modern infrastructure, the company is trying to offer to its business partners logistics services of better quality. The modern technology provides for faster operations which essentially increases the goods flow speed. In addition to the excellent location and the entire offer provided by the space enabling provision of all services (terminal, storage, distribution, customs, freight and inspection), the possibility for finding logistics solutions for opening production plants in the South-East Europe additionally contributes to the company's competitiveness. The competitive opportunities associated with the expansion of the logistics activities include the following facts:

- provider of logistics services,

- individual treatment of each business partner and joint decisions, 
- customized e-commerce, tracking goods, storage capacity and product manipulation,

- several years of experience in logistics.

\subsubsection{SWOT Analysis of the company's logistics centre}

The competitive advantages are specific resources, skills and knowledge based on which the company can achieve its objectives (Tab. 2).

\begin{tabular}{|c|c|}
\hline A. ADVANTAGES: & B. DISADVANTAGES: \\
\hline $\begin{array}{l}\text { - Location (good traffic connections, easy } \\
\text { availability). } \\
\text { - Good knowledge of the Slovenian market and } \\
\text { the Balkans. } \\
\text { - Quality of services, adjustability. } \\
\text { - Several years of experience in field of the } \\
\text { business activity, modern equipment } \\
\text { - Typification of internal transport and storage } \\
\text { equipment and information support (use of } \\
\text { the barcode system and RFID-technology). } \\
\text { - Knowledge and continuous learning. } \\
\text { - Desire and need for progress and } \\
\text { development. } \\
\text { - Possibility for storage and distribution of } \\
\text { goods. }\end{array}$ & $\begin{array}{l}\text { - Partially inadequate staff (lower level of } \\
\text { education). } \\
\text { - Underdevelopment of brands (lower } \\
\text { recognisability). } \\
\text { - Lack of marketing strategy. } \\
\text { - Not present in foreign markets (without own } \\
\text { branches, and the customers are supplied from } \\
\text { Slovenia). } \\
\text { - Limited range of logistics services. }\end{array}$ \\
\hline C. OPPORTUNITIES: & D. RISKS: \\
\hline $\begin{array}{l}\text { - Outsourcing logistics trend. } \\
\text { - Development of the Slovenian market for } \\
\text { logistics services. } \\
\text { - Entering foreign markets. } \\
\text { - Integration of goods flow. } \\
\text { - Connecting companies (networking). }\end{array}$ & $\begin{array}{l}\text { - Risk of new companies entering the logistics } \\
\text { branch due to its attractiveness. } \\
\text { - Lack of infrastructure. } \\
\text { - Small Slovenian market. } \\
\text { - Increase of transport costs, lack of proper } \\
\text { knowledge in Slovenia. }\end{array}$ \\
\hline
\end{tabular}

Tab. 2. SWOT analysis for LC

The disadvantages are those activities of the company that threaten its success by obstructing or delaying the achievement of the defined objectives. The opportunities are favourable circumstances in the external environment of the company. If the company knows how to use them, they will provide for achieving the set goals. The risks of the company are unfavourable changes in its external environment and they represent an obstacle to the achievement of the desired objectives (Kremljak et al., 2012).

\subsubsection{Proposal for products logistics of the buyer in future} It includes:

- The supply of equipment and acquisition (storage of raw materials and auxiliary materials) shall be entered in the system (it is recorded as stocks in export department). 
- The products of each customer shall be entered into the program (customs tariff, product description, pattern, colour, design and ordered quantity) and during the preparation of the work, based on the buyer's purchase order, the production facility orders are launched, which include the same information as in the program (pattern, colour, model, size and quantity in certain colour).

- The next step is printing out forms with barcodes used for tracing the product throughout the production beginning from the cutting unit to the dispatch unit which will be sewn to the product. This includes printing our double labels:

a) paper labels used for tracing the product throughout the production beginning from the cutting unit to the control unit and they will be sewn into the product,

b) self-adhesive labels affixed to the cardboard label of the ordering party. In the control unit this label replaces the sewn paper label. This label is used for reading out the products that are loaded in a truck for the purpose of writing them off from the stocks in the storage.

- The display of the paper and self-adhesive labels shall be according to a time schedule, i.e. first the paper label and then the self-adhesive label and these are being sent for the preparation of the operations:

a) the paper label shall be inspected and forwarded to the cutting unit,

b) the self-adhesive labels, after the inspection, are delivered to the export department and shall be affixed to the cardboard labels of the client and returned to the storage of auxiliary materials,

c) in future on the cardboard labels of the ordering party will be printed the data with the company's barcode, as well as the trading data, model, colour, size, pattern and Made in EU). Attention should be paid because the ordering party has triple cardboard labels and it is required to indicate the type of label for a certain pattern. To implement this, we need a program, printer, label cutting machine. The printing labels should be in rolls.

- The next step is the production in the cutting and sewing unit (at this point the paper label will be sewn to the basis of the product) and the ironing unit.

- When the products arrive in the control unit, the paper label shall be replaced with a cardboard label of the ordering party on which is affixed our barcode and the products will be adjusted.

- After putting the product in stock in the warehouses (by reading the barcode) a list of orders transferred in the warehouse shall be prepared on daily basis.

- Every day at a certain time, the IT department must prepare a report and the person in charge of orders shall review the report and send it to ordering party. This report shall include the following data: pattern, model, colours, quantity of products by size and colour for the launched quantities, the cut quantities and the quantities taken over to the warehouse, as well as launched pieces. At the end there should be a single sum of the total quantity of products for a certain pattern in a certain colour, taken to the warehouse. The display program shall operate in such a way in which the patterns will be automatically displayed as follows:

a) the difference between the pieces in the warehouse and the launched products must be 0 ,

b) the patterns defined as write-downs and write-offs must be automatically displayed, minus those that were taken over for launching. 
Kremljak, Z. \& Hocevar, M.: Restructuring a Production Company Into a Productio...

When the products are loaded onto a truck, the barcode of each product must be read and the total dispatch note for all products that are being loaded must be printed. By printing the dispatch note, the stocks in the warehouse are being reduced (Zigart, 2008).

\subsubsection{Launching future orders}

Due to the modified method of product delivery, the orders must be launched in another way, namely:

- The pattern is entered in the same way and the link between the export department and the production department continues to exist.

- The model is entered in the same way - simple entry where there is no connection between the export and preparation department.

\section{Preparations for storage system solution}

In the preparation for systematic solution of storage of finished products a realization in stages is planned. The most important thing is the organization of an integrated information system in the warehouse of finished products. This is part of a complex project, which consists of three stages:

- improvement of the level of automation in existing warehouses (assembly of hanging conveyors, logistics automation),

- extension of warehouses for finished products for handling the increased production of products,

- organization of IT support.

\subsection{Solutions in the field of IT support}

Based on the information about the orders, stocks, the production plan and the dispatch orders, the daily task of the dispatch department is to organize the work today for tomorrow or in the morning for the current day. The properly designed information system based on timely, accurate and uniform data must automate and standardize the work as much as possible.

The information on planned quantities are received by the individual plants through a computer-supported system of daily schedules for the production of finished products based on manufacturing sequences for production of products within the sliding planning system (Kremljak, 2010).

The system has the following advantages:

- based on the capacity of the hanging conveyors in the warehouses and the work schedule the daily or weekly work plan is being developed;

- the automatic monitoring of the production realization in real time records surpluses/shortages, provides current information about the logistics of the realized and the upcoming production.

In this way the data on the planned production are processed applying unified method, in a common database and through a computer network they will be delivered to the dispatch department. The receipt of the information on the realized production is automatic based on a barcode read by the system checkpoints (Fig. 6). 
There is a proposal for the company to implement an open-closed storage system, which means that the products are being dispatched not only from the stocks, but also from the production. Based on the barcode read by the readers that are installed at handover points between production and logistics, the computer programs must provide automatic write-off of production and loading the stocks of the central warehouse (Zigart, 2008).

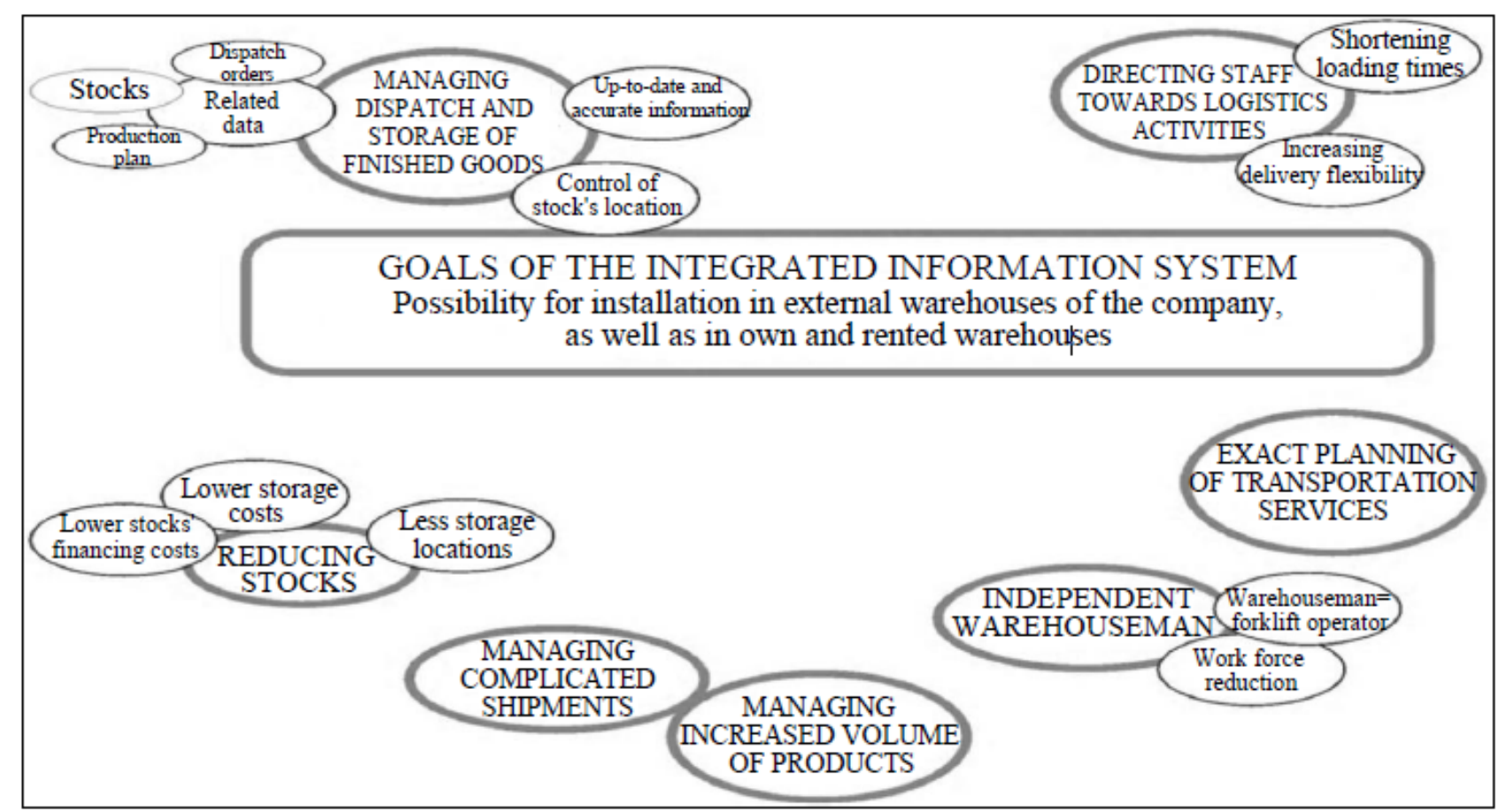

Fig. 6. Goals of the integrated information system

When storing the products, the data from the barcode readers are used for directing the products to the storage places. The computer should locate an empty space for storing the products. The computerized process itself has no real meaning without investing in automation of the processes for classification of the products in the storage logistics units and the introduction of technology for automatic detection of the location in which the product is placed. Taking out products of the warehouse involves removing the products from the temporary storage place, and the barcode reader shall read the product data and the data of the field in which the product was placed. These data are used for unlading the stocks of a particular field. When loading items in the means of transport, the barcode readers control the accuracy of the consignment's composition and at the same time they provide data which, by means of integrated data processing, enable preparation of all necessary supporting documents and writing-down the stocks in the warehouse.

\section{Conclusion}

In the article we are describing the solution for a textile company which had to adapt rapidly to prevent its existence. By commissioning products for the customers, the vision of the company to transform from a production company into production logistics company is fulfilled. With the applied organisation form the company will become more competitive on the pretending European market by reducing production 
Kremljak, Z. \& Hocevar, M.: Restructuring a Production Company Into a Productio...

costs, labour costs, as well as by reducing the number of employees.

The restructuring of individual profiles in the production logistics centre will provide for greater flexibility of the company, and in terms of the costs it will become more competitive on long-term basis and it will increase its market share.

Our future plans include the implementation of this type of logistics system also to other partners in the company's supply chain. In the next step the entire logistics will be completed by the company, including the delivery of goods to the end customers.

Original contribution in the article is how to convert the production manufacturing company in manufacturing logistic centre. Serious competition in the clothing industry provides conditions, which are developed and implemented in real sector, confirms the correctness and effectiveness of the decisions.

\section{References}

Al-Hawari, T.; Ahmed, A.; Khrais, S. \& Mumani, A. (2013). Impact of assignment, inventory policies and demand patterns on supply chain performance. International Journal of Simulation Modelling, Vol. 12, No. 3, 164-177

Anderson, E. G. \& Morrice, D. J. (2000). A simulation game for service-oriented supply chain management: Does information sharing help managers with service capacity decisions?. Production and Operations Management, Vol. 9, No. 1, 40-55 Gilbert, S. M. \& Ballou, R. H. (1999). Supply chain benefits from advanced customer commitments. Journal of Operations Management, Vol. 18, No. 1, 61-73.

Kremljak, Z. (2010). Capability development in business system in the uncertainty conditions. International Journal of Services Operations and Informatics, Vol. 5, No. 3, 231-251

Kremljak, Z.; Hocevar, M.; Kafol, C. \& Buchmeister, B. (2012). Supply chain and identification of risks with heuristic tools. TTEM - Tech. Technol. Educ. Manag., Vol. 7, No. 4, 1717-1726 (http://www.ttem.ba/pdf/ttem_7_4_web.pdf)

Maleki, M.; Bashkite, V. \& Machado, V. C. (2012). Integration of supply chain performance with customer values through combining analytical network process and Bayesian network, Proceedings of the $23^{\text {rd }}$ Int. DAAAM Symposium, Katalinic, B. (Ed.), 297-300, ISBN 978-3-901509-91-9, Zadar, October 2012, DAAAM Int. Vienna

Ouyang, Y. \& Li, X. (2010). The bullwhip effect in supply chain networks. European Journal of Operational Research, Vol. 201, No. 3, 799-810

Pujawan, I. N. (2008). Schedule instability in a supply chain: an experimental study. International Journal of Inventory Research, Vol. 1, No. 1, 53-66

Rudberg, M. \& Olhager, J. (2003). Manufacturing networks and supply chains: An operations strategy perspective. Omega, Vol. 31, No. 1, 29-39

Simchi-Levi, D.; Kaminsky, P. \& Simchi-Levi, E. (2003). Designing and managing the supply chain, McGraw-Hill, New York

Zigart, J. (2008). Logistika v tekstilni industriji Val d. d. (Diploma thesis: Logistics in textile industry Val d. d.), Maribor (http://www.doba.si/diplome/11100060290.pdf) 